Ворович Б. О., канд. військ. наук, доцент

(0000-0002-4083-3707)

Центр воєнно-стратегічних досліджень Національного університету оборони України імені Івана Черняховського, Київ

\title{
Шляхи вирішення проблемних питань розмінування території України
}

Резюме. У статті розглянуто шляхи вирішення проблемних питань розмінування території держав, де мали місце воєнні конфлікти, зокрема території України.

Ключові слова: мінна безпека; розмінування; вибухово-небезпечні пристрої; протимінна діяльність; інженерні війська.

Постановка проблеми. Питання мінної безпеки держав, на території яких мали місце воєнні конфлікти, а це понад 60 країн світу, $\epsilon$ пріоритетним і актуальним на сьогодні день. За даними [1] після завершення збройних конфліктів установлено і знаходиться у бойовому положенні понад 110 млн мін та інших вибухово-небезпечних пристроїв (ВНП) різних типів. Понад 100 млн мін зберігаються на військових арсеналах, складах і базах та готові до застосування. Досвід розмінування в різних регіонах показує, що за рік знешкоджується не більше ніж 3-5\% встановлених мін Крім втрат цивільного населення, тварин і матеріальних засобів із землекористування виведені величезні території.

3 досвіду бойових дій в зоні АТО на сході України ГШ ЗС України заявлено, що бойові втрати ВС України 3 початку проведення АТО (квітень 2014 року) і до кінця жовтня 2019 року склали - 10710 військовослужбовців, 3 них 2333 загиблих. Втрати серед мирного населення - на 2300 загиблих військових доводиться 10000 загиблих цивільних. За період виконання робіт з розмінування підрозділами ЗС України перевірено на наявність вибухонебезпечних предметів 133 га території. Виявлено та знешкоджено (знищено) 72866 од. ВНП.

Унаслідок підривів на вибухонебезпечних предметах 3 початку проведення АТО, включно 2018 рік, на території Донецької та Луганської областей загинуло та поранено 942 військовослужбовця (це приблизно $10 \%$ від бойових втрат ВС України), знищено та пошкоджено понад 110 од. військової техніки $[2,5]$.

3 огляду на реальну існуючу мінну небезпеку для військ і населення України виникає необхідність щодо пошуку шляхів вирішення проблемних питань розмінування території України, розроблення ефективніших засобів і методів розмінування з урахуванням новітніх досягнень науково-технічного прогресу.

Аналіз останніх досліджень i публікацій. Питання мінної безпеки держав $\epsilon$ також одним 3 найбільш пріоритетних в діяльності $\mathrm{OOH}$, а його реалізація бачиться в здійсненні протимінної діяльності (ПМД). 3 метою координації дій та розроблення міжнародних стандартів під егідою $\mathrm{OOH}$ в Женеві створений Міжнародний центр 3 питань розмінування в гуманітарних цілях. Цим центром уведено в дію "Керівництво 3 розроблення законодавства стосовно діяльності, яка пов'язана 3 розмінуванням", відповідно до якого визначені основні види діяльності пов'язані з ПМД у світі, зокрема розроблені стандарти ООН з гуманітарного розмінування.

У публікаціях $[1,3,5,8,9]$ дослідників протимінної безпеки та розмінування, як іiі складової, відсутній системний аналіз цієї проблеми і не розглянуті можливі шляхи іiі розв'язання з урахуванням інтересів України та сучасних досягнень у науці і техніці. Не приділено належної уваги щодо можливостей проведення гуманітарних акцій 3 метою розмінування території України.

Мета статті - пошук шляхів щодо вирішення питань розмінування території України, а також підвищення ефективності розмінування в умовах збройного конфлікту 3 урахуванням досвіду інженерного забезпечення дій частин (підрозділів) 3С України в АТО.

Викладення основного матеріалу. Мінна зброя дає змогу протягом тривалого часу контролювати певний простір i значну частину місцевості, а у разі масового застосуванні у вигляді мінних полів, перешкоджати діям противника в місцях установки ВНП, не витрачаючи до того ж додаткових сил i засобів. Міни виявилися найдешевшою оборонною зброєю і через це стали застосовуватися в масовій кількості. 
Розглянемо ситуацію “мінна безпека" в двох напрямах - глобальному i національному.

Глобальна ситуація. Проблема ліквідації наслідків воєнних конфліктів, а саме мінної безпеки залишається на територіях колишньої Югославії, Кавказьких республік, в Іраку, Афганістані, Сирії, країнах Південносхідної Азії (Кампучія, Лаос, В'єтнам), Південній Африці, Близькому Сході і багатьох інших регіонів світу.

На першому місці списку за кількістю загиблих і потерпілих від вибухів ВНП є Афганістан, Сирія, Смен і М'янма.

Тільки за 2018 рік у світі від ВНП загинули або отримали поранення 6897 чоловік. Більшість жертв - мирні жителі, більше половини - діти. Статистика охоплює тільки офіційно зареєстровані і підтверджені випадки смерті [3].

Одним 3 найбільш значущих чинників, що стримує розв'язання проблеми розмінування, $€$ недостатньо висока ефективність зразків техніки i технологій пошуку і знешкодження мін та інших ВНП. Ще одним аспектом, що перешкоджає розв'язанню проблеми, $\epsilon$ різноманіття ВНП і умови виконання робіт.

Аналіз досвіду застосування ВНП у локальних війнах i збройних конфліктах, a також у прикордонних конфліктах показує, що застосуванню мін притаманні такі характерні риси: замість протяжних мінних полів, зазвичай встановлюються невеликі групи мін i навіть окремі міни (останне особливо характерно для мін-фугасів і мін-пасток); мінні групи й окремі міни найчастіше ставлять безсистемно і не фіксують у документах, розповсюджується установка керованих мін (зокрема фугасів і пасток); мінні поля, групи мін частіше прикривають вогнем; використовується величезна кількість мін, детонаторів і вибухових речовин кустарного та саморобного виготовлення, небезпечних у виробництві i застосуванні для самих виробників.

Національна ситуащія. Досвід ведення війни на сході України підтверджує, що одним 3 напрямів забезпечення надійної оборони ЗС України є застосування ВНП, який також масово використовує противник, що призвело до того, що нині Україна п'ята у світі за кількістю жертв від ВНП. Аналіз застосування ВНП в зоні АТО показує, що ВНП розкидані по всій території конфліктної зони, особливо уздовж лінії бойового зіткнення і являють собою серйозну загрозу для особового складу, озброєння і техніки, цивільних осіб, включаючи дітей. На сьогодні замінована територія складає понад 7000 кв. м $[3,5]$.

На практиці в Україні існує такий підхід для розв'язання проблеми очищення територій від ВНП:

підрозділи Міністерства оборони України здійснюватимуть заходи військового розмінування (це, насамперед, розмінування на лінії розмежування, полігони та об'єкти, які до нього належать);

оперативне розмінування здійснюватимуть підрозділи Державної служби України 3 надзвичайних ситуацій (ДСНС) - це розмінуванням на мирній території.

Державна служба транспорту займається розмінуванням на транспортних комунікаціях, СБУ - у разі загрози терактів.

У світовій практиці існує ще такий напрям розв'язання проблеми очищення територій від ВНП як гуманітарне розмінування. Воно виконується за міжнародними стандартами діяльності, пов'язаної 3 розмінуванням (IMAS), але проводиться там, де немає бойових дій. До гуманітарного розмінування, що адмініструється центральними органами виконавчої влади, можуть залучатися підрозділи Міноборони, ДСНС або приватні структури на конкурентних засадах через відповідні тендерні процедури.

Досвід показує, що жодна країна, що стикається 3 необхідністю розмінування територій після військових дій, не може розв'язати цю проблему власними силами, тобто бюджетними коштами, тому звертається за допомогою до міжнародних та вітчизняних офіційних постачальників послуг гуманітарного розмінування. На сьогодні фінансування цього напряму здійснюють дві міжнародні організації, які працюють в Україні:

Danish Demining Group (Датська група 3 розмінування) - відділ 3 питань безпеки людини при Датській Раді у справах біженців, який спеціалізується на очищенні територій від мін та боєприпасів, а також зменшенні збройного насильства;

HALO Trust - британська благодійна i американська некомерційна організація із розмінування сухопутних територій.

Згідно 3 міжнародними стандартами 3 питань розмінування в гуманітарних цілях залучення кампаній з розмінування, потребує створення та втілення в життя відповідної законодавчої бази в Україні. 
Раніше, Указом Президента України (ПУ) від 2 вересня 2013 року № 476/2013 “Про національний орган України 3 питань протимінної діяльності” було визначено: “Покласти на Міністерство оборони України здійснення функцій національного органу України з питань протимінної діяльності”, але міжнародний досвід свідчить про те, що країни 3 меншим економічним розвитком та авторитарною системою обирають шлях створення національних програм 3 протимінної діяльності на базі міністерства оборони, а країни з більшим економічним розвитком виділяють гуманітарне розмінування в окремий вид діяльності, що дає змогу залучити міжнародну допомогу та уникнути виконання Міноборони не властивих йому функцій. У країнах, де протимінним центром виступає міністерство оборони, обсяги міжнародного фінансування (допомоги) для виконання програм 3 протимінної діяльності в десятки разів менший. I ще - світова практика доводить, що певні структури, які проводять дотації на гуманітарне розмінування, не фінансуватимуть “міліарні” структури [7].

Ураховуючи зазначене, Указ Президента України від 02.09.2013 № 476/2013 втратив чинність на підставі Указу Президента України від 20.06.2019 № 419/2019.

Новим Законом України "Про протимінну діяльність в Україні" від 06.12.2018 № 2642-VIII визначається:

перелік об'єктів та суб'єктів протимінної діяльності, порядок їх створення, організаційні та процедурні засади діяльності; вимоги до фахівців у сфері розмінування та їх обов'язки;

джерела фінансування протимінної діяльності;

порядок обліку операторів протимінної діяльності, надання допомоги постраждалим особам (жертвам) від вибухонебезпечних предметів; тощо.

процес передачі очищеної території

У Законі зазначено, що функції Національного органу з питань протимінної діяльності покладаються на Державну комісію 3 питань техногенно-екологічної безпеки та надзвичайних ситуацій під головуванням Прем'єр-міністра України, яка забезпечує координацію діяльності міністерств, інших центральних та місцевих органів виконавчої влади, органів місцевого самоврядування, підприємств та організацій незалежно від форми власності.

Зі свого боку, рішення Національного органу 3 питань протимінної діяльності приймаються колегіально за участю усіх зацікавлених центральних органів влади, та $\epsilon$ обов'язковими до виконання, що відповідає міжнародним стандартам 3 протимінної діяльності. Крім того, для планування, практичної організації та координації здійснення заходів протимінної діяльності передбачається створення оперативних органів протимінної діяльності, а саме Центру протимінних операцій та Центру гуманітарного розмінування.

Пропонується розроблена перспективна схема організації протимінної діяльності в Україні (рис. 1), яка має бути затверджена КМ України [8].

Втілення в життя Постановою Кабінету Міністрів України вказаної схеми організації протимінної діяльності забезпечить вимоги міжнародної спільноти щодо протимінної діяльності, виконання іiі програм та взагалі практичної реалізації на території Україні.

Минуло понад рік, як набув чинності Закон України "Про протимінну діяльність в Україні" (з 25 січня 2019 року), але й досі не визначений персональний склад Державної комісії 3 питань техногенно-екологічної безпеки та надзвичайних ситуацій, який $є$ Національним органом з питань протимінної діяльності, i, як наслідок, немає налагодженої організації управління протимінною діяльністю в Україні.

Міністерство оборони України прикладає всі зусилля для найскорішого вирішення питань розмінування території держави. Завершилася робота щодо акредитації i сертифікації за напрямом “протимінна діяльність". На сьогодні 143 Центр розмінування (м. Кам'янецьПодільський) є єдиною структурою в Україні, що організовує i постійно проводить підвищення кваліфікації спеціалістів 3 розмінування за міжнародними стандартами IMAS (на підставі ліцензії від 20.05.2008, серія АВ № 420043, затвердженої наказом Міністра освіти і науки України від 28.05.2008 № 1824-л) в інтересах всіх зацікавлених міністерств та відомств відповідності до Закону України від 22.12.2004 № 2281-IV "Про прийняття Протоколу про вибухонебезпечні предмети - наслідки війни”. Усього за період існування Центру розмінування підготовлено більше 4200 фахівців 3 розмінування для різних 
міністерств та відомств. Успішне виконання миротворцями завдань у Республіці Ірак, Південному Лівані, Сьєрра-Леоне, Косово, Ліберії та позитивні відгуки закордонних фахівців свідчать про високий рівень підготовки українських фахівців 3 питань розмінування.

\section{CXEMA}

організації протимінної діяльності в Україні на перспективу

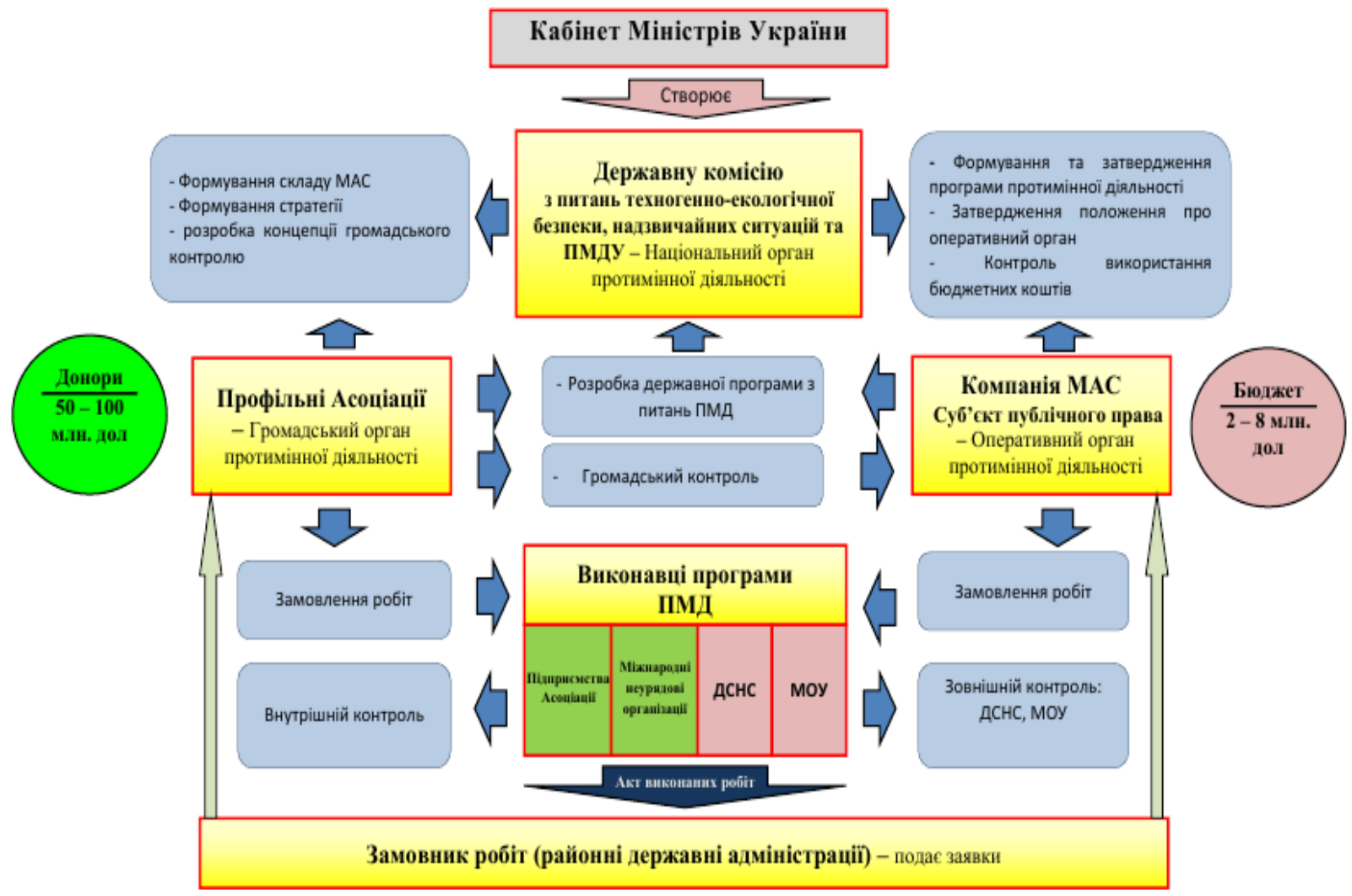

$\square^{\text {умовні позначення }}$ - функції та завдання

- суб์'єкти діяльност

\section{Рис. 1. Перспективна схема організації протимінної діяльності}

Продовжується робота над акредитацією Центру розмінування як органу 3 оцінювання контролю якості, для отримання атестату органу інспектування, який підтверджує спроможність проводити контроль якості розмінування.

3 метою впровадження міжнародних стандартів протимінної діяльності в Україні Управлінням екологічної безпеки та протимінної діяльності Міністерства оборони України із залученням провідних спеціалістів у сфері протимінної діяльності міжнародних організацій ОБСС, ПРООН, Женевського центру гуманітарного розмінування та інші. розроблено національний стандарт "Протимінна діяльність. Процеси управління. Основні положення" [9].

Стандарт розроблено, насамперед, для забезпечення використання всіма суб'єктами протимінної діяльності єдиної термінології в цій сфері; забезпечення дотримання заходів безпеки під час проведення робіт 3 нетехнічного, технічного обстежень та очищення/розмінування; забезпечення прав та інтересів громадян, пов'язаних 3 мінами та ВНП; збереження навколишнього середовища i виконання взятих державою міжнародних зобов' язань 3 питань протимінної діяльності.

В Україні офіційним постачальником послуг гуманітарного розмінування для $\mathrm{OOH}$, (реєстраційний № 113908, номер акредитації UNOPS/MAU/015/2008) є Державне підприємство "Укроборонсервіс" і приватна компанія “Трансімпекс". Вони беруть активну участь у державних та міжнародних проєктах 3 протимінної діяльності для потреб ООН, силових відомств та протимінних центрів країн, забруднених мінами $\mathrm{i}$ виступають активним учасником на ринку надання послуг у сфері виявлення та очищення територій від мін і вибухонебезпечних предметів.

Нині ЗС України мають найбільші спроможності щодо проведення розмінування. Кількість і спроможності інженерних військ, які здатні проводити розмінування, в рази більші ніж ДСНС. Фактично знищення 
більшості виявлених ДНСН та неурядовими організаціями мін та снарядів, що не вибухнули, здійснюють підрозділи ЗС України. Зі слів колишнього начальника Управління екологічної безпеки та протимінної діяльності МО України полковника М. Комісарова $80 \%$ всіх виявлених у зоні конфлікту боєприпасів у країні знищують підрозділи ЗС України, хоча відповідно до законодавства, більша частина території держави закріплена саме за ДСНС [9].

На сьогодні завдання 3 розмінування в районі операцій об'єднаних сил виконують приблизно 30 груп розмінування ЗС України. Треба врахувати і той факт, що інженерні війська, крім заходів із розмінування, виконують на сході держави багато різноманітних завдань інженерного забезпечення військ.

Як приклад, на рис. 2 наведено обсяг виконання заходів 3 гуманітарного розмінування в зоні АТО силами ЗС України [9].

Законодавство дозволяє Міноборони України проводити розмінування в зонах його відповідальності і об'єктів у повному обсязі, однак повноваження 3 контролю над гуманітарним розмінуванням без попереднього (нормативного) узгодження, не можливе.

3 огляду на великий досвід 3 розмінування, Міністерству оборони України мають бути законодавчо визначені такі основні функції протимінної діяльності: розмінування, знищення та знешкодження ВНП; підготовка спеціалістів та фахівців 3 ПМД; навчання протидії ризикам, пов'язаним 3 ВНП; знищення запасів ВНП; ведення інформування (пропаганди незастосування ВНП); миротворчої діяльності; знищення ВНП, непридатних для подальшого використання i зберігання; реабілітація та допомога жертвам підриву ВНП.

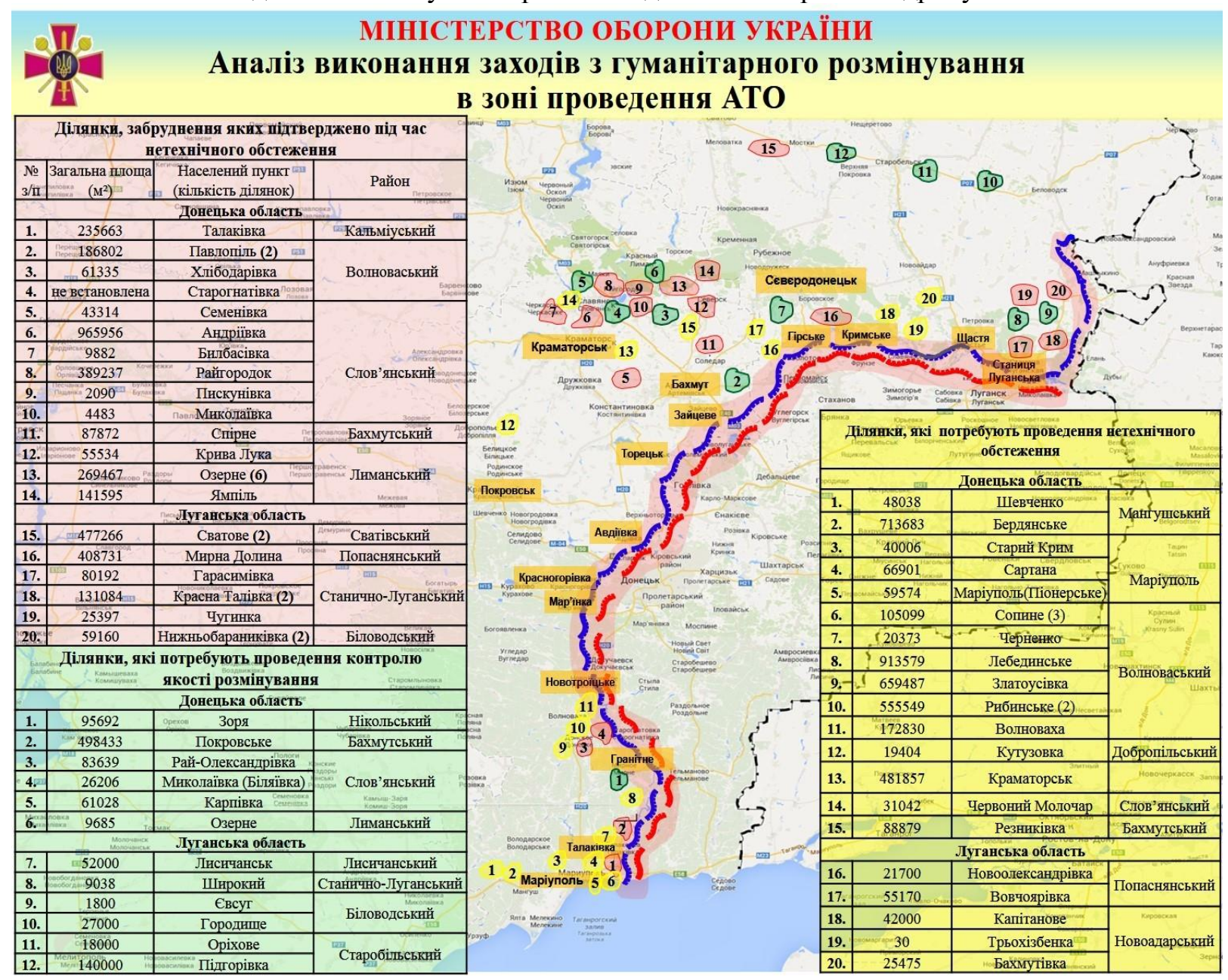

Рис. 2. Обсяг виконання заходів з гуманітарного розмінування в зоні АТО силами ЗС України

У зонах активних бойових дій проводити гуманітарне розмінування небезпечно, тому для обстеження та розмінування мінних полів доцільно вивчити та проаналізувати світовий досвід, залучити безпілотні літальні апарати (дрони), роботизовану техніку, що керується дистанційно та готувати відповідних фахівців. 
Подібні засоби можуть працювати набагато швидше та ефективніше, ніж сучасна саперна техніка. Практичні дії з розмінування мінних полів безпілотними літальними апаратами показують, що в середньому знешкодження однієї міни коштує від \$300 до $\$ 1000$, у той час, як вартість дрону складає в середньому \$1000-2000 і зможе забезпечити повне розмінувати декількох мінних полів [10].

Висновки. Чисельні втрати військовослужбовців, цивільного населення i матеріальних засобів, як в умовах воєнного конфлікту так i мирного часу, потребують звернути якомога швидше увагу на протимінну діяльність в державі. Не зважаючи на проведену певну роботу 3 порушеного питання, проблема протимінної діяльності в Україні залишилась остаточно невирішеною.

Основними серед можливих шляхів підвищення ефективності розмінування території України в сучасних умовах $\epsilon$ :

удосконалення існуючої нормативноправової бази протимінної діяльності та втілення ऑiі у сферу протимінної діяльності, для чого необхідно визначити персональний склад і розпочати роботу Державної комісії 3 питань техногенно-екологічної безпеки та надзвичайних ситуацій, яка є Національним органом з питань протимінної діяльності;

упорядкування виконання завдань протимінної діяльності військових (цивільних) формувань, що підпорядковані різним міністерствам та відомствам, державним та комерційним організаціям на території України.

Робоча група з розроблення нормативноправових документів про протимінну діяльність в Україні має перейняти кращий досвід 3 цього питання в державах Хорватії, Таджикистану, де до процесу розмінування залучено як державні, так i комерційні структури, але під відомчим контролем і гарантією державної відповідальності.

Надалі доцільно проводити наукові дослідження щодо підвищення ефективності та удосконалення зразків техніки (особливо роботизованої), технологій пошуку i знешкодження мін та інших ВНП 3 урахуванням сучасних досягнень науки та техніки.

\section{СПИСОК ВИКОРИСТАНОЇ ЛІТЕРАТУРИ}

1. Доповідь "Land mine Monitor 2019". Мюнхенська міжнародна неурядова організація Handicap International.

2. Доповідь Начальника Генерального штабу ЗСу 6.12.2017. URL: https://vesti.ua/politika/268357poroshenko-nazval-chislo-pohibshikh-soldat-zavremja-ato (дата звернення: 04.03.2020).

3. Курсеітов Т. Л., Нероба В. Р. Прихована загроза. Військовий вісник. №10, 2019.

4. Куницький С. В. 50 років на розмінування. Військовий вісник. №10, 2019.

5. Україна - п’ята в світі за кількістю жертв вибухів мін. URL: https://m.censor.net.ua/news/ 3161155/

ukraina_pyataya_v_mire_po_kolichestvu_jertv_vzry vov_min_doklad (дата звернення: 05.03.2020).

6. Ядовиті зерна війни. URL: http://www.artofwar.net.ru/ profiles/andreev_pavel_v/view_book/iadovitye_ zerna_voiny (дата звернення: 27.02.2020).

7. Особливості гуманітарного розмінування. URL: https://www.radiosvoboda.org/a/29685254.html (дата звернення: 27.02.2020).

8. Перспективна схема організації протимінної діяльності в Україні. URL: http://audm.org.ua/wpcontent/uploads/Shema-PMDU-perspektiva-1.pdf (дата звернення: 04.03.2020).

9. У мін немає оборотного ходу. Тижневик №15 (861), 19.04.2018p. URL: https://www.2000.ua/vnomere/ derzhava/ekspertiza/u-miny-net-obratnogohoda.htm] (дата звернення: 04.03.2020).

10. Мосов С. П., Гурак С. П. Роботи та БПЛА проти мін. Оборонний вісник. № 11, 2019.

Стаття надійшла до редакційної колегії 24.03.2020

\section{Ways to solve the problem of demining the territory of Ukraine}

\section{Annotation}

Based on statistics provided by the General Staff of the Armed Forces of Ukraine since the beginning in the area of the anti-terrorist operation, the combat losses amounted up to 10,710 servicemen, of which 2,333 were killed. There are about 10,000 civilian deaths in the 2,300 military personnel killed. During the period of demining operations, units of the Armed Forces of Ukraine inspected 133 hectares of territory for the presence of explosive devices, 72,866 units of explosive objects were detected and neutralized (destroyed).

From 2014 to 2018, 942 servicemen were killed and wounded on explosive devices in Donetsk and Luhansk regions (10\% of the combat losses of the Armed Forces of Ukraine), and more than 110 units of military equipment were destroyed and damaged.

The purpose of the article is to find ways to address the issues of demining of the territory of Ukraine and increase the efficiency of demining, considering the experience of engineering support units of units of the Armed Forces of Ukraine during the anti-terrorist operation. 
The main possible ways to increase the efficiency of demining of the territory of Ukraine in modern conditions are:

improvement of the existing normative-legal base of mine action, for which it is necessary to determine the personnel and start the work of the State Commission on Technogenic-Ecological Safety and Emergencies, which is the National Body on these issues;

streamlining the implementation of mine action tasks of military (civilian) formations of other ministries and departments, state and commercial organizations on the territory of Ukraine.

Keywords: mine safety; demining; explosive devices; mine action; engineering troops. 